\title{
Reflections
}

\section{Mayo clinic}

\section{H.S. Adenwalla}

Department of Plastic Surgery and Burns, the Charles Pinto Centre for Cleft Lip, Palate and Craniofacial Anomalies, Jubilee Mission Medical College and Research Institute, Trichur, Kerala, India, Smile Train Medical Advisory Board (South Asia and New York)

Address for correspondence: Dr. H.S. Adenwalla, Department of Plastic Surgery and Burns, the Charles Pinto Centre for Cleft Lip, Palate and Craniofacial Anomalies, Jubilee Mission Medical College and Research Institute, Trichur - 680005 , Kerala, India. E-mail: charlespinto102@gmail.com

he Mayo clinic one of the greatest medical centers of the world, had the most humble beginnings and like so many historic events, it was the conglomeration of many factors that made the Mayo clinic what it is today. The Mayos-the father and his two sons had established their practice in Rochester. Tuesday, August the $21^{\text {st }} 1883$ was a very hot day in Rochester, the heat was stifling and residents hopefully watched black storm clouds pile up and anticipated a storm and a shower, hoping that this would give them some relief from the searing heat.

About 6'O clock in the evening William and Charles Mayo their day's work done started off in a buggy to the slaughter house to get a sheep's head upon which to practice an eye operation that night. When they reached their destination they found the butchers heading for home to avoid the storm and they strongly advised the young doctors to do the same. They barely passed the river bridge when they saw it torn from its hinges by the wind and shattered to bits. They saw a house lifted in part and in pieces by the wind and parts of it broke the wheels and shaft of their buggy. The horse was loosened from the carriage and bolted and the brothers were blown along the way. They found their horse with difficulty and took shelter in a black smith's shop. As luck would have it the roof blew away, they hugged the walls with the

\begin{tabular}{|l|l|}
\hline \multicolumn{2}{|c|}{ Access this article online } \\
\hline Quick Response Code: & Website: \\
\hline & www.ijps.org \\
\hline & Dol: \\
\hline
\end{tabular}

horse until the storm subsided and started heading for home. They however, soon realized that great damage was done by the storm, many had died and hundreds lay injured and medical help was badly needed. They turned back into the town to help. The father had taken charge of a large centre in a hotel, some doctors were working in patient's homes, and a host of patients with severe wounds and fractures were lying in the convent of the sisters of St. Francis. It was there that William and Charles Mayo gravitated and worked through the night and all of next day and well in to the next night. The work went on for days some lived, many died. Mothers and daughters of the town volunteered to nurse the injured but the elder doctor Mayo thought he would do better with a more dedicated nursing team. The teaching sisters of St. Francis were at home in their mother house for the summer vacations. He asked for them and the Mother Superior Mother Alfred willingly gave this services.

Shortly before the storm John Ireland, Bishop of St. Paul in whose diocese Rochester lay had suggested to Mother Alfred that Rochester needed a hospital. She was against the idea, for theirs was a teaching congregation, and she said, "We know nothing about nursing", and that hospitals

\footnotetext{
This is an open access article distributed under the terms of the Creative Commons Attribution-NonCommercial-ShareAlike 3.0 License, which allows others to remix, tweak, and build upon the work non-commercially, as long as the author is credited and the new creations are licensed under the identical terms.
}

For reprints contact: reprints@medknow.com

How to cite this article: Adenwalla HS. Mayo clinic. Indian J Plast Surg 2015;48:227-30. 
were unpopular with the public, people thought that patients went to hospitals only to die. After the disaster that struck Rochester she changed her mind. She asked the elder doctor Mayo if starting a hospital was a good idea. He said no it wasn't, people preferred to be treated at home or in the doctor's clinics. However, Sr. Alfred persisted and Dr. Mayo ultimately relented. He and his sons agreed to work in the hospital if the sisters could finance the building. For four years the hospital remained only an idea but it was not shelved. By hard work and frugal living the sisters of St. Francis collected the money, they went through unbelievable hardships and at last the land was bought at two thousand two hundred dollars. Dr. Mayo was asked to give his plan for the building. Father and the elder son made a tour of the bigger hospitals in America and ultimately after many changes handed in their plans to Mother Alfred. There was much excitement in Rochester as they saw this magnificent edifice come up. The sisters decided to open the hospital on the $1^{\text {st }}$ of October 1889 . The Mayos however, had a major operation the day before on the $30^{\text {th }}$ of September. The theater was ready-so with characteristic disregard for pomp or ceremony the doctors Mayo began their work the day before the opening. The operation was for removal of a malignant tumor of the eye. The first entry in the operation registered reads operating surgeon Dr. Charles Mayo, Assistant Dr. W.J. Mayo, Anaesthetist Dr. W.W. Mayo [Figure 1].

The policy of the hospital was clearly stated. The hospital was a Catholic hospital for charity. Any doctor could admit his patients and treat them. Mother Alfred in her opening speech said "The cause of suffering humanity knows no religion and no sex; the charity of the Sisters of St. Francis is as broad as their religion".

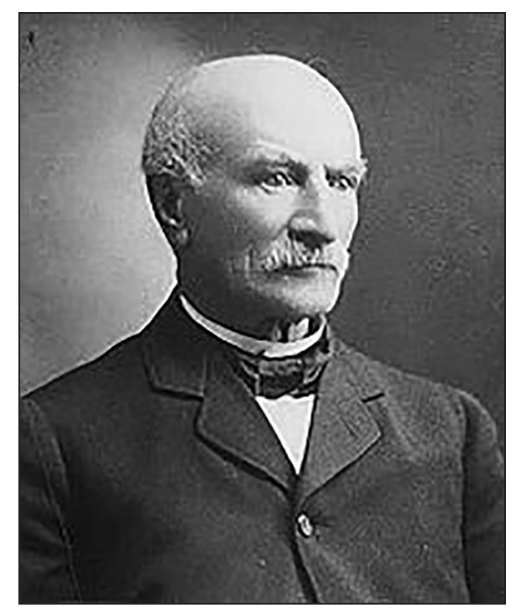

Figure 1: William Worrall Mayo, the founding father of what would become the Mayo Clinic
But soon trouble was to start. The Protestant families were reluctant to support a Catholic institution. The doctors who were friendly to the Mayos refused to join an institution which they believed was doomed to fail. The Catholic families were sore that the sisters had not asked a young Catholic doctor of a prominent Catholic family in Rochester to have something to do with the hospital. To make things worse some of the Sisters of St. Francis too were not pleased with the Mayos for dragging them out of their familiar and comfortable teaching establishments and made a strong representation to Archbishop, Ireland. The hospital was really his brain child but he did something quite unfair and quite unexpected, he removed mother Alfred from her position as head of the congregation, uncomplaining mother Alfred took personal charge of the St. Mary's Hospital. She remained in-charge till 1890 looking after every aspect of the hospital's administration.

All this time she was grooming Julia Dempsey of Rochester who had taken the habit as Sr. Joseph. In 1878 she took up nursing duties at St. Mary's hospital and she was eventually made head of the hospital. It is said that, that was perhaps the luckiest day for St. Mary's hospital. Sr. Joseph became Dr. William's Shadow in the early days Dr. Mayo had to examine a male patient completely stripped Sr. Joseph her modesty outraged turned her back on the patient, put her hands on her face and begged Dr. Mayo to return her to her teaching duties. Years later a visitor observed that once when Dr. Mayo was operating he turned to explain something at length to the surgeons observing him when he turned back to continue with the operation, to his surprise Sr. Joseph had completed the next step.

When one opposing factor subsided another arose Dr. Allen, a Homeopathic physician with a large practice opened another hospital in rented buildings. He called it the riverside hospital and opened it to all doctors. This encouraged the Protestants of Rochester to rise again against the Catholic run St. Mary's hospital. This made a dent in the number of patients that went to St. Mary's. At this juncture two important members of the Presbyterian church fell ill and were admitted at the Riverside. The Dr. Mayo's were called to attend. They very wisely refused. It was a difficult decision for which they were heavily censured. The Mayos knew that the riverside could never match the infrastructure and nursing of St. Mary's and besides the Mayos felt a strong moral 
obligation to the sisters of St. Francis. For two years the Mayos were in an uncomfortable situation. But suddenly Dr. Allen announced that he was moving to St. Paul and the Riverside hospital was closed down. The St. Mary's hospital and the Mayos had turned a critical corner after that they never looked back. They had the backing of the best hospital in a very wide area where the medical aid was poor and surgical expertise almost nonexistent.

At the near end of their lives Dr. William Mayo told their biographer "We were no magicians, no exceptional men, when you write, stress the unusual opportunities that existed at the time, the place, the general set up which can never be duplicated now or ever". But their epic story proved that these three-the father and the two brothers were no ordinary men and their humility was the hallmark of their greatness. They stood at the threshold of a new era in surgery heralded by anaesthesia and antiseptic surgery which was soon replaced by aseptic techniques. Surgeons hesitated to remove an inflamed appendix and most doctors treated intestinal obstruction conservatively operating only as a last resort when the patient was dying, which gave surgery a bad name. Men like the Mayo brothers, Benjamin Murphy, William Halstead and Harvey Cushing in America and a host of others in England and Europe broke every barrier in surgery daring to do what was never done before, opening the three body cavities with impunity and removing diseased organs for these men did not know for sure then if a man could live without a gall-bladder or a spleen or a lung or how much of the stomach or intestines or the thyroid could be spared and yet the patient could survive.

William the elder was the better speaker. He restricted himself to the abdomen. Charles operated on everything else. The elder brother once said, "My brother was the better surgeon he drove me down to the belly", when they spoke it was always "My brother and I" or another oft heard refrain from them was "Our Father taught us".

There is a touching story about William Mayo and it is one of many about the Mayos. A young lad of 17 years was brought to him for a major abdominal problem by a well-wisher who could not pay. William Mayo spoke to the boy and said "Look here my boy I have to operate on you and it is going to cost you 100 dollars. Can you pay?", "No sir", said the boy "I haven't any money". "Alright", said the doctor "after you get well you can work and send me 10 dollars every month". After a reasonable period of time the 10 dollars started coming every month till the
100 was paid. The doctor sent back a cheque to the boy for a 100 dollars and added the interest for the money that took over a year to pay. With the money he wrote to the boy a note "Bank the money son and let it grow, you know and I knew that you could do it" [Figure 2].

Charles Mayo died of pneumonia on the $26^{\text {th }}$ of May 1939, William Mayo died two months later of cancer of the stomach. Strange to say a condition he had dealt with thousands of times. A copy of the resolution adopted by the surgical society of the Mayo clinic reads.

"Those in years to come pursue these minutes may justly question as to what manner of men were we who, experiencing bereavement such as our in recent months, yet inadequately expressed it. Let them remember, then, that those whose greatness they strive to recreate from graven names and printed pages were living men with whom we talked and walked and laughed; our preceptors, our colleagues, and our friends. We were too close to this grief to describe it. "True sorrow makes a silence in the heart". There is now left for us their precedent-that immortal part of them-to cherish and to hand on. They worked for something even greater than themselves. Gradually at first, then more definitely, as old age approached, they withdrew from the affairs of this clinic encouraging their successors to plant their feet firmly. They kept to themselves no knowledge or skill which they could impart to younger men, and they took pride in their growth. Always available at any hour for consultation or advice, yet they did not assume authority in another surgeon's case. Guidance without pampering; help without meddling; those are the principles by which we were trained. Let us then train others thereby and as we close ranks for the years ahead as our great

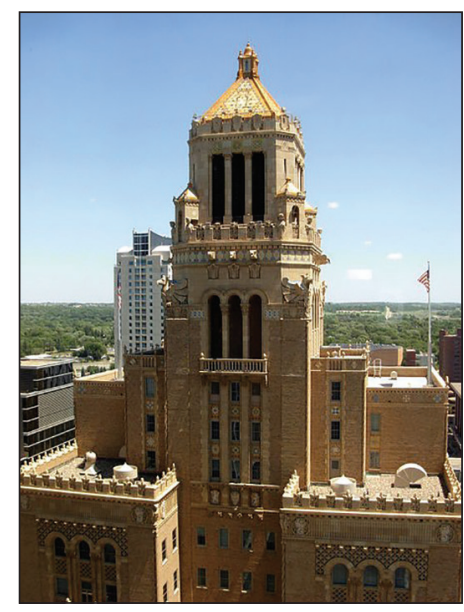

Figure 2: Mayo Clinic Plummer Building

Indian Journal of Plastic Surgery May-August 2015 Vol 48 Issue 2 


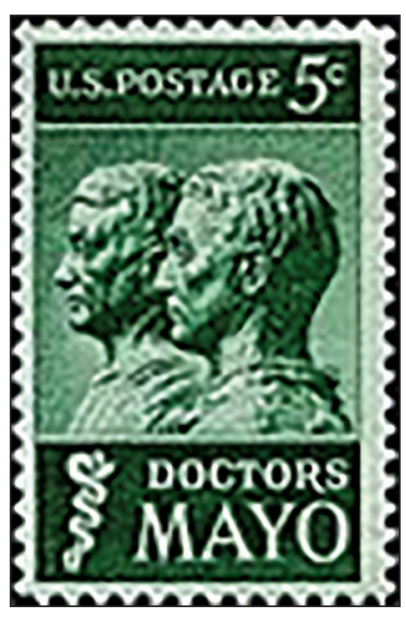

Figure 3: A five-cent stamp was issued in 1964 honoring the "Pioneers of Group Practice," Dr. William and Dr. Charles Mayo, who founded the Mayo Clinic in 1889

mentors would have had us do, let it be said of us as was said of them "They helped everyone his neighbour" [Figures 3 and 4].

In time to come men may raise shafts of stone and piles of bricks to the memory of William and Charles Mayo, but so long as their spirit endures in the clinic they created they will have a monument more fitting a living memorial in their own image. In their own time and over the years the St. Mary's hospital grew into what is called the Mayo clinic

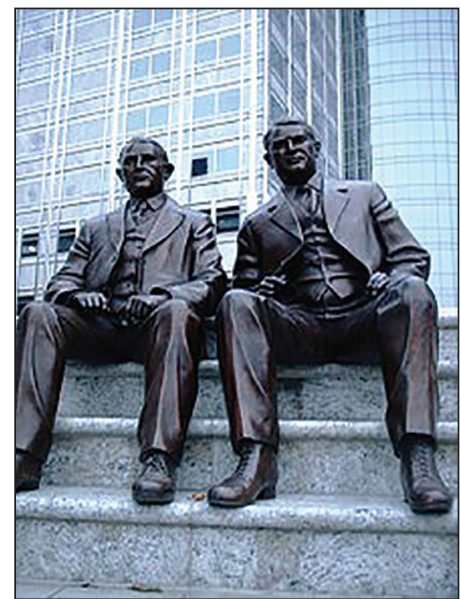

Figure 4: Bronze sculpture, by Tuck Langland, of the Mayo brothers, "Dr. Charlie" (left) and "Dr. Will" (right), in front of the Mayo Clinic

almost the size of a small city, but tucked away somewhere among those giant buildings the old St. Mary's hospital still-stands where surgeons go from all over the world to pay homage to the memory of the two brothers William James and Charles Horace Mayo.

\section{Financial support and sponsorship} Nil.

\section{Conflicts of interest}

There are no conflicts of interest. 